\title{
RESISTIVE SENSOR FOR HIGH-POWER MICROWAVE PULSE MEASUREMENT
}

\author{
Ž. Kancleris, M. Dagys, and R. Simniškis \\ Semiconductor Physics Institute, A. Goštauto 11, LT-01108 Vilnius, Lithuania \\ E-mail: kancleris@pfi.lt
}

Received 15 September 2004

Dedicated to the 100th anniversary of Professor K. Baršauskas

\begin{abstract}
A resistive sensor the performance of which is based on electron heating effect in semiconductors is presented. The device is devoted for high-power microwave pulse measurement. Waveguide-type resistive sensors are considered. Their test results at working conditions are presented. Novel trends in resistive sensor design are discussed and a coaxial-type resistive sensor for the measurement in a wide frequency range is presented.
\end{abstract}

Keywords: hot carriers, microwave detectors, microwave measurement, measurement standards

PACS: $72.20 . \mathrm{Ht}$, 85.30.De

\section{Introduction}

Nowadays different types of pulsed high-power microwave (HPM) oscillators and amplifiers are being researched in laboratories, as well as being manufactured by the industry [1]. They are used in communication systems, radars, microwave test facilities, scientific research, and military projects. Sources generating tens of GW HPM pulses have been developed. It should be noted that the measurement of the HPM pulses involves some technical problems since devices that can measure HPM pulses directly are not produced by industry. For this reason the standard devices devoted for low-power microwave pulse measurement are commonly used for HPM applications.

At present two techniques are employed to measure the output power of pulsed microwave sources. The first one is based on average power, pulse duration, and repetition rate measurements. The second one relies on the direct conversion of microwave pulse to the DC pulse using calibrated diodes. Both these methods can be applied for HPM pulse measurement but suffer from some drawbacks. Determination of the pulse power from the measured average power can be successfully applied for the measurement of rectangular shape pulses. It is of little use when low repetition rate or single pulse characteristics are controlled. It should be noted that shape of pulses produced by HPM sources are far from ideal and low repetition rate or even single pulses are generated. For the direct HPM pulse measurement, calibrated diodes can be used, but they can handle a very low power level. Therefore, the HPM pulse should be strongly attenuated before being directed to the diode. Large attenuation results in the decrease of the measurement accuracy. In addition, when measuring milliwatts, diode outputs the DC pulse of the order of millivolts. Direct measurement of such pulse might be problematic in the presence of stray pick-up and electromagnetic field interference that are typical of the environment of HPM sources.

In the present paper an alternative device - resistive sensor (RS) - for HPM pulse measurement is presented. The proposed device is free from the shortcomings mentioned above. Waveguide-type RSs are considered. Novel trends in RS design are discussed and the coaxial-type RS for the measurement in a wide frequency band is presented.

\section{Sensing element}

The performance of the RS is based on the wellknown electron heating phenomenon in semiconductors [2]. When strong electric field pulse is applied to a semiconductor, a new steady state of the electron system is established with the mean electron energy much greater than the equilibrium energy. Heated electrons, 


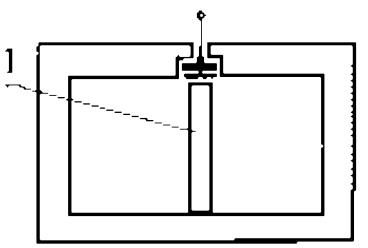

(a)

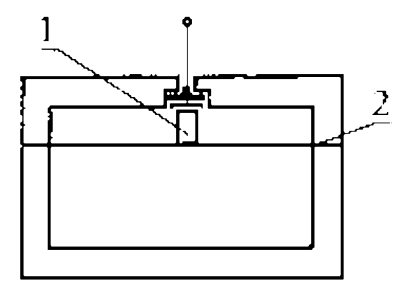

(b)
Fig. 1. Schematic cross-section of (a) the cross-waveguide-type RS and (b) the diaphragm-type RS: (1) sensing element, (2) metal diaphragm.

as a rule, are scattered more frequently by the lattice imperfections and the resistance of a semiconductor in a strong electric field increases. Since the resistance change of the semiconductor is put as a basis of the RS operation, the sensing element of the RS is actually a resistor made from $n$-type $\mathrm{Si}$ with ohmic contacts on its ends. The sensing element is inserted into transmission line (usually waveguide). The microwave electric field heats the electrons in the sensing element, and its resistance thereby increases. Thus, by measuring this resistance change microwave pulse power in the transmission line is determined. Connecting the current source to the sensing element, the output signal from it can be expressed in the following form:

$$
U_{\mathrm{S}}=U_{0} \varphi\left(E_{\mathrm{m}}\right),
$$

where $U_{0}$ is a DC voltage drop on the sensing element and $\varphi$ is the relative resistance change of the sensor obtained by averaging instantaneous current over the period of microwave electric field $E_{\mathrm{m}}$. Since the amplitude of the electric field in the sensing element depends on power transmitted through the line with the sensor, thus, by measuring $U_{\mathrm{S}}$ the pulse power in the transmission line can be determined. It is obvious that, to get the absolute values of the power, the RS should be calibrated.

\section{Waveguide-type RS}

Two types of RSs are mainly used for the measurement of microwave pulse power in the waveguide. Their sketches are shown in Fig. 1. It is seen that RS is designed as a standard waveguide section with a sensing element mounted in it. The sensing element of the cross-waveguide-type RS is mounted in the centre of the waveguide (Fig. 1(a)). Its length corresponds to the narrow wall of the waveguide. Typically, these sensors are mainly used for the measurement of intermediate levels of pulse power ( $\sim 1 \mathrm{~kW}$ at X-band).
In order to improve the thermal characteristics of the sensor and widen its possible applications, the diaphragm-type RS shown in Fig. 1(b) has been developed. The sensing element is mounted under a thin metal diaphragm and the wide wall of the waveguide. The height of the sensing element roughly corresponds to $1 / 10$ of the waveguide's narrow wall.

At least two advantages of the diaphragm-type RS over the cross-waveguide-type RS can be mentioned. By decreasing the length, the average heating of the sensing element is reduced significantly because the heat relaxation time is proportional to the square of the length of the sensing element. Since the sensing element occupies only part of the waveguide window, a smaller voltage standing wave ratio (VSWR) can be achieved when a lower specific resistance semiconductor is used as the sensing element. Diaphragm-type RSs have been manufactured and tested beginning from $\mathrm{L}$ up to Ka-band. Such sensors have found application in measuring nanosecond-duration HPM pulses as well.

\subsection{Comparison with pulse power standard}

Due to the big difference in inertia between electron and thermal sensor heating, the same sensor can serve as a pulse power meter and thermistor bolometer. Thus, the possibility exists of calibrating the sensor by replacing the microwave electric field in the sensor by a DC electric field the strength of which can be measured with high accuracy. Such technique has been applied to the X-band cross-waveguide-type RS at low power levels where the output signal linearly depends on pulse power [3].

To check the method of replacement, the readings of the calibrated RS have been compared with the former Soviet Union pulse power standard held at the Institute of Radiophysical Measurements (VNIIFTRI) in Moscow.

Three X-band cross-waveguide-type RSs have been manufactured and calibrated using the replacement method described in more detail in [3]. Calibration of the RS has been performed at a frequency $9.43 \mathrm{GHz}$ using a rectangular $10 \mathrm{~W}$ microwave pulses whose duration can be changed in the range 10-100 ms. The rise and fall times of the pulses were less than $0.3 \mathrm{~ms}$. The repetition rate is adjusted depending on the pulse power and its length to get an average heating of the sensor in the range of $1-2 \mathrm{~K}$. The temperature of the RS is maintained with accuracy $\pm 0.01 \mathrm{~K}$.

The readings of the calibrated RSs were compared with the readings of pulse power standard [4]. Testing was performed at the same frequency using 4-6 W 


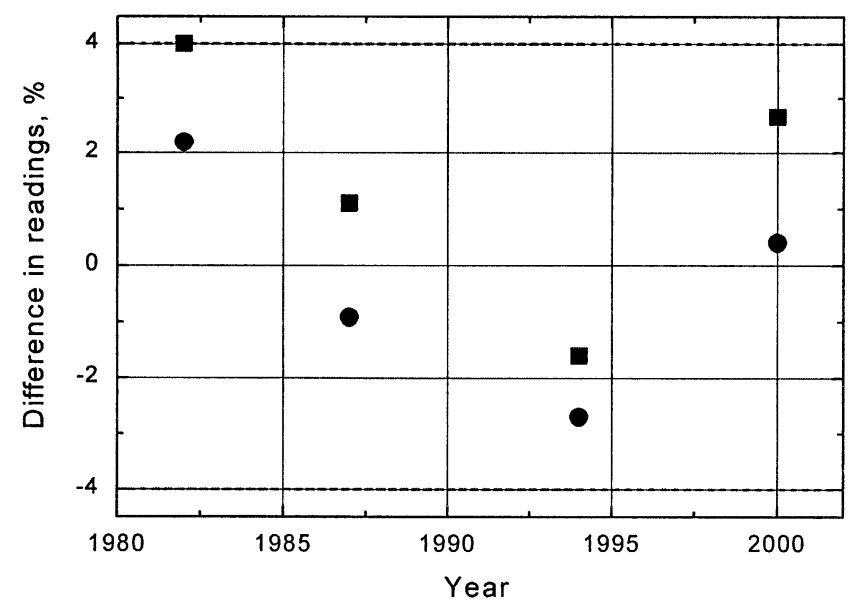

Fig. 2. The comparison of the readings for two different crosswaveguide-type RSs with the Russian (former Soviet Union) pulse power standard.

pulses. It was found that the standard deviation of the readings was less than $4 \%$ for all three RSs. Agreement between readings of the standard and the RS seems to be good, since the main error of the pulse power standard at that time was $\pm 4 \%$.

Two calibrated RSs that are regularly used as reference pulse power meters at the microwave laboratory were compared with the standard since 1982 [3]. The last comparison has been done in 2000 . The results of this long-term experiment are presented in Fig. 2. It is seen that some change of the sensitivity is observed. Nevertheless, taking into account the main error of the standard $( \pm 4 \%)$, it is evident that the tested sensors show sufficiently good long-term stability.

\subsection{Short HPM pulse measurement}

Most powerful HPM pulse generators produce pulses the duration of which is of the order of few tens of ns. To use the RS for short HPM pulse monitoring requires improved response time. Since stray pick-up and electromagnetic interference is typical in the environment of HPM sources, it is desirable to increase the output signal of the RS without employing electronic circuitry for signal amplification.

As it follows from Eq. (1), the output signal of the RS increases linearly with DC voltage drop on the sensing element. Unfortunately, the increase of DC voltage applied to the sensing element is restricted by its heating. To overcome this problem, the pulsed DC supply synchronized with the measuring pulse has been used for RS feeding. Technical details of the measurement circuit are described in [5]. The output signal dependences on pulse power for the different frequency

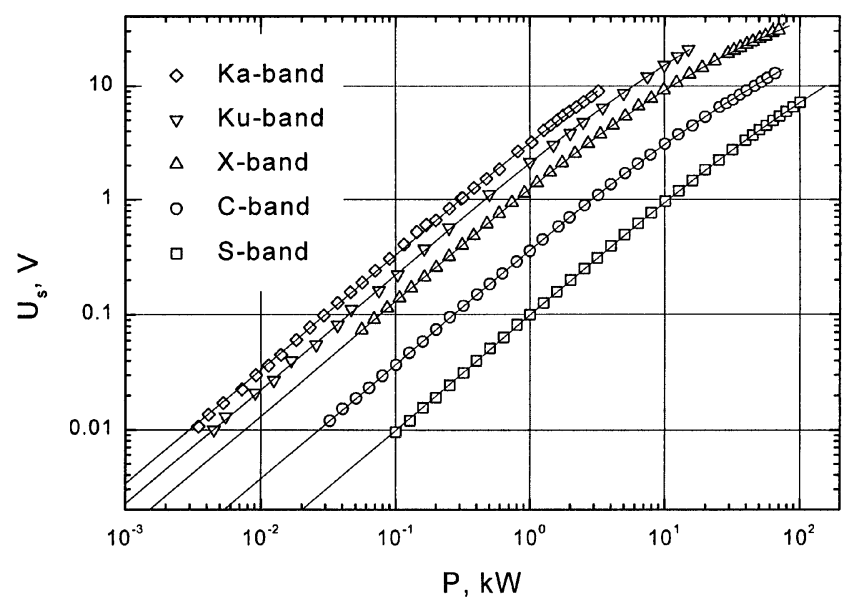

Fig. 3. Output signal dependences on pulse power for the RS designed for short HPM pulse measurement. Points denote experimentally measured values, solid lines correspond to the fitting of measured dependence by quadratic polynomial.

band RS measured using $50 \mathrm{~V}$ amplitude DC pulses are shown in Fig. 3. It is seen that using DC pulse feeding output signals up to $30 \mathrm{~V}$ are obtained without any amplification. It should be pointed out that the RS has been calibrated up to pulse power levels available in the laboratory. They can likely be used at higher pulse power levels, ultimately limited by air breakdown in the waveguide.

Electron heating inertia is a physical reason that limits the response time of the RS. Characteristic time of this process in $n$-type $\mathrm{Si}$ is of the order of $2.9 \cdot 10^{-12} \mathrm{~s}$, therefore, it should be the limit of the response time of the RS. However, the sensing element is connected in a DC circuit and the parameters of this circuit such as inductance, capacitance, and the resistance of the sensing element are responsible for the actual response of the RS.

The equivalent circuit of the RS consists of the inductance of the wire that connects the sensing element to the coaxial connector, and the capacitance that is connected in parallel with the sensor's resistance to prevent the leakage of microwaves out of the waveguide. Wishing to improve the response time the resistance of the sensing element is decreased down to $10-20 \Omega$. The capacitance is chosen from the condition $2 \pi \bar{f} C \geq 5 \Omega^{-1}$, where $\bar{f}$ is the central frequency of a particular frequency band. The impedance of the line that connects the sensing element with the coaxial cable is adjusted individually for each device.

The response time of the RS was estimated making use of the so-called time domain reflectometry method. The sensor is fed by a DC pulse with a subnanosecond rise time, and by measuring the duration of the transient 
Table 1. Response time of the diaphragm-type RS devoted for short HPM pulse

\begin{tabular}{lccccc}
\multicolumn{7}{c}{ measurement. } \\
\hline \multicolumn{1}{c}{ Frequency band } & $\mathrm{S}$ & $\mathrm{C}$ & $\mathrm{X}$ & $\mathrm{Ku}$ & $\mathrm{Ka}$ \\
\hline Waveguide size $\left(\mathrm{mm}^{2}\right)$ & $72 \times 34$ & $40 \times 20$ & $23 \times 10$ & $17 \times 8$ & $7.2 \times 3.6$ \\
Frequency range $(\mathrm{GHz})$ & $2.6-4.0$ & $5.0-7.0$ & $8.2-12.4$ & $14-18$ & $26.5-40$ \\
Response time $\tau(\mathrm{ns})$ & 2.5 & 2 & 0.5 & 0.4 & 0.2 \\
$\tau \cdot \bar{f}$ & 8 & 10 & 5 & 7 & 7 \\
\hline
\end{tabular}

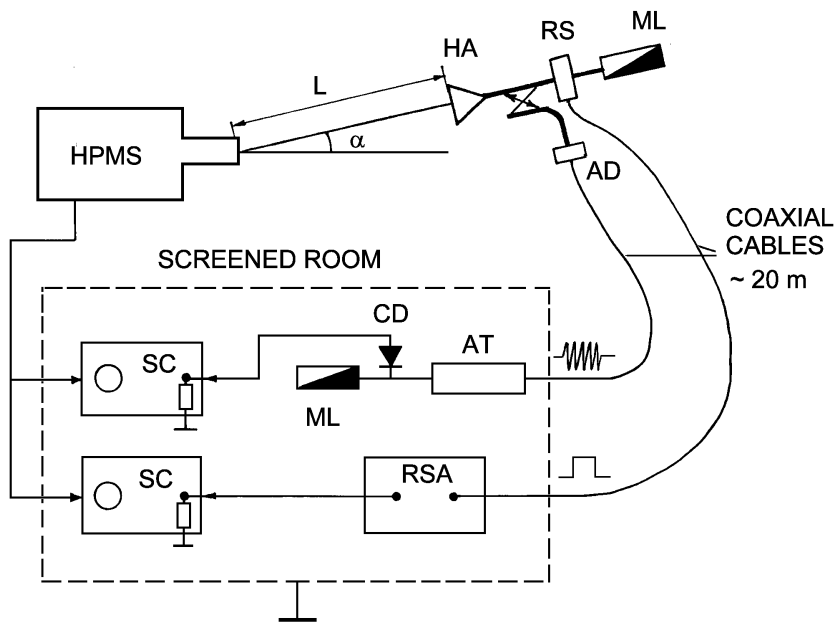

Fig. 4. Experimental set-up for HPM pulse power measurement in free space: HPMS, high-power microwave source; HA, horn antenna; RS, resistive sensor; ML, matched load; $\mathrm{AD}$, waveguide-tocoaxial cable converter; AT, attenuator; $\mathrm{CD}$, diode; RSA, DC pulse adapter; SC, oscilloscope.

formed by the initial and reflected pulse, the response time of the RS can be determined. Measurement results of the diaphragm-type RS for different frequency bands are listed in Table 1. It is seen that as the frequency decreases, the response time of the RS increases. This is because at lower frequency a larger capacitance has to be used to prevent the leakage of microwaves out of the waveguide. Nevertheless, at every frequency band the response time is less than $10 / f$. This means that the RS can measure microwave pulses with duration of the order of a few tens periods of microwave oscillations.

Tests of the X-band RS under operational conditions using short HPM pulses were performed at the University of New Mexico. HPM pulses are generated using SINUS-6 electron beam accelerator to drive backward wave oscillators [6]. The maximum pulse power is roughly $500 \mathrm{MW}$ with duration of 5-7 ns. The carrier frequency was in X-band and a single shot operation was employed.

The experimental set-up for the measurement of HPM pulse power in free space is shown in Fig. 4. The HPM source radiates microwaves into free space.
A measuring unit is placed at a distance $L$ from the source and shifted at an angle $\alpha$ from the symmetry axis of the HPM source. It consists of a horn antenna, a directional coupler, the RS, and a matched load. The RS directly measures microwave pulse power received by the horn antenna. Microwave pulses are transmitted from the directional coupler $(20 \mathrm{~dB})$ via coaxial cable (attenuation $\sim 10 \mathrm{~dB}$ ) and the additional coaxial attenuator to feed a calibrated diode. The maximum pulse power that can be measured by the diode is roughly $20 \mathrm{~mW}$. Therefore, total attenuation of the HPM pulse before it is measured by the diode is in the range of 50-60 dB. The pulse shapes and the amplitudes are registered in a screened room by oscilloscopes. The response time of the diode is less than $1 \mathrm{~ns}$. Thus, by comparing the shapes of the HPM pulses detected by the RS and the diode, we were able to check the response time of the RS.

Experimental results of detected pulses are shown in Fig. 5. The amplitudes of the pulses are normalized to the maximum pulse power detected by the particular device. As one can see from the figure, the shapes of both pulses are practically identical, so it can be concluded that the response time of the RS is not worse than the rise time of the diode.

\section{Coaxial-type RS}

Unfortunately, the waveguide-type RS that was presented in the previous section is not free from some drawbacks. First, the frequency range where the particular device can be used is restricted by the bandwidth of the particular waveguide. Second, the sensitivity of the RS in the waveguide's band is frequency dependent: the maximum-to-minimum sensitivity ratio in the frequency range of $8.2-12.4 \mathrm{GHz}$ is roughly 2.7 . It seems that the same sensitivity variation should be characteristic of the RS for other frequency bands.

Therefore, our recent efforts have been focused on a coaxial-type RS (CRS) that are free from the shortcomings mentioned above. The CRS is seen as a device that is able to measure HPM pulses over a wide frequency range. Therefore, it should maintain the main advan- 


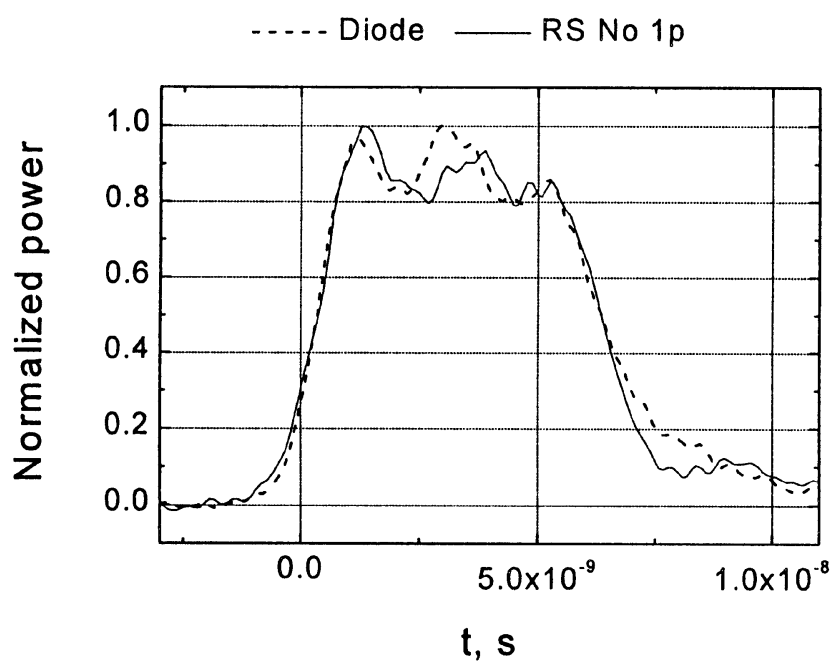

(a)

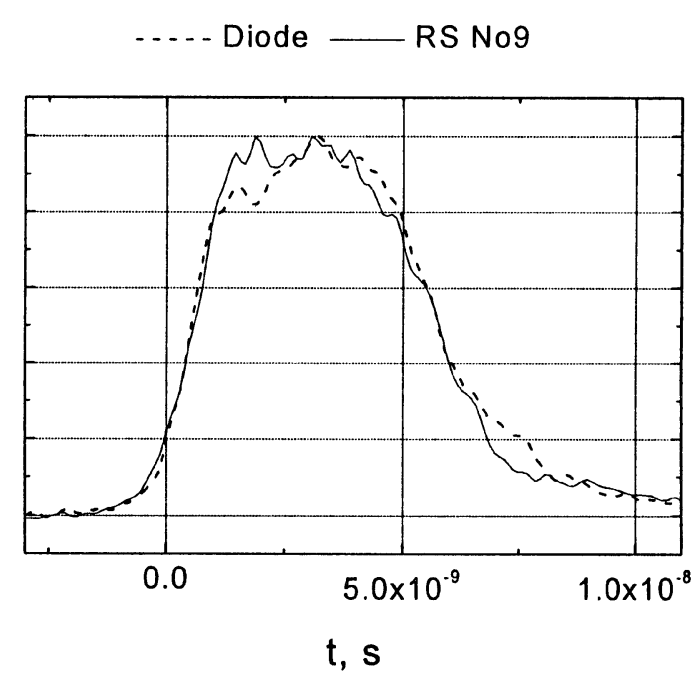

(b)

Fig. 5. The shapes of short HPM pulses detected (a) by the diode and (b) by the RS.

tages of the RS keeping the other principal characteristics at the same level as a conventional detector. We accept the following desirable CRS characteristics: frequency range $2-12 \mathrm{GHz}$, maximum pulse power $1 \mathrm{~kW}$, and $\mathrm{VSWR} \leq 1.6$.

\subsection{Concept}

The CRS can be considered as a two-terminal device. One terminal is used to connect the sensor to a coaxial line where the measuring microwave pulse is propagating. The other terminal connects the CRS to the measuring circuit and sensor feeding unit. We used a $50 \Omega$ impedance coaxial line as a basis for the CRS design because waveguide-to-coaxial line adapters are usually fitted to $50 \Omega$ impedance lines. Therefore, it should not be a problem to connect the CRS to the different band waveguides making use of standard adapters.

The CRS actually consists of the sensing element and a low-pass filter. The latter prevents propagation of the microwave pulse directly to the DC pulsemeasuring device and provides matching of the sensor with the coaxial line.

\subsection{Realization}

The general view of the CRS is shown in Fig. 6. It is seen that the sensing element and low-pass filter are placed in a parallelepiped-shaped metal box. The total length of the device is roughly $10 \mathrm{~cm}$, the width $2.5 \mathrm{~cm}$, and the height $2 \mathrm{~cm}$. The CRS is connected to the coaxial line using an N-type connector. A feeding circuit

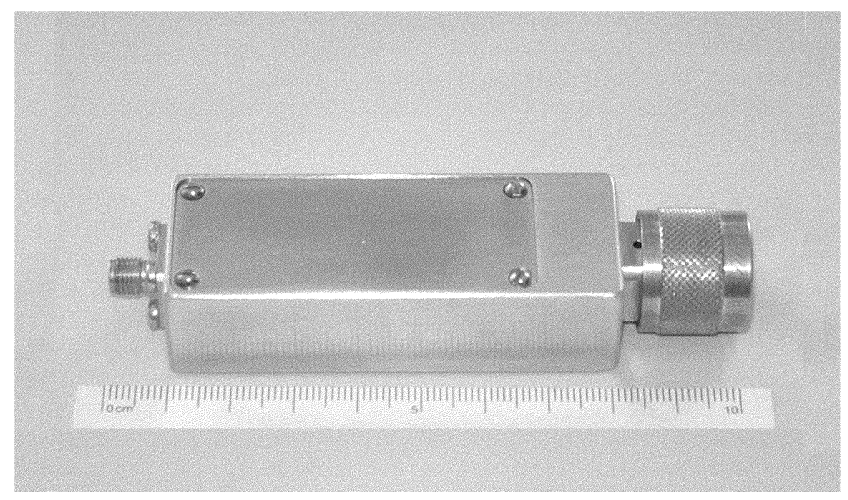

Fig. 6. The general view of the coaxial-type RS.

and DC pulse-measuring device is attached to the CRS using an SMA-connector.

A few CRS designs with five-element Butterworth type low-pas filter were tested. The filters were composed of lumped elements and microstrip line sections. The hybrid filter made from both lumped and distributed elements was also investigated.

The reflection coefficient of the CRS has been measured in a frequency range $1.25-12.0 \mathrm{GHz}$. Measurement results for the CRS with different types of filters are presented in Fig. 7. The solid line in the figures denotes the desirable limit value of VSWR $=1.6$.

The dependence of the reflection coefficient on frequency for the CRS with a lumped element filter exhibits low values of the reflection coefficient in the frequency range 1.25-6.0 GHz (Fig. 7(a)). At higher frequency the electrical length of the lumped elements becomes too large in comparison with the microwave's wavelength, this is the reason why some resonance occurs, and the peaks are seen in the dependence of the 
(a) $f_{c}=0.75 \mathrm{GHz}$, lumped element filter

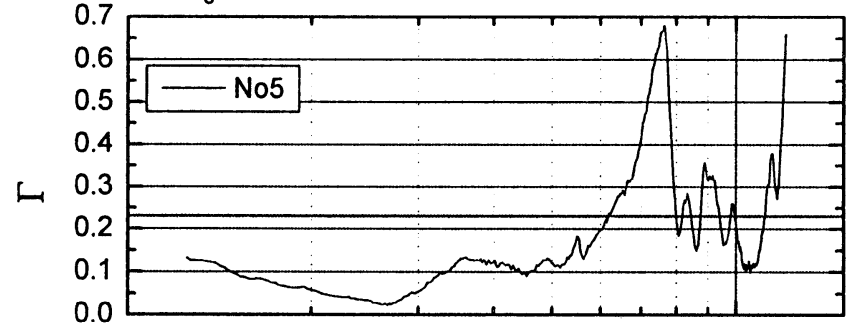

(b) $f_{c}=0.5 \mathrm{GHz}$, hybrid filter

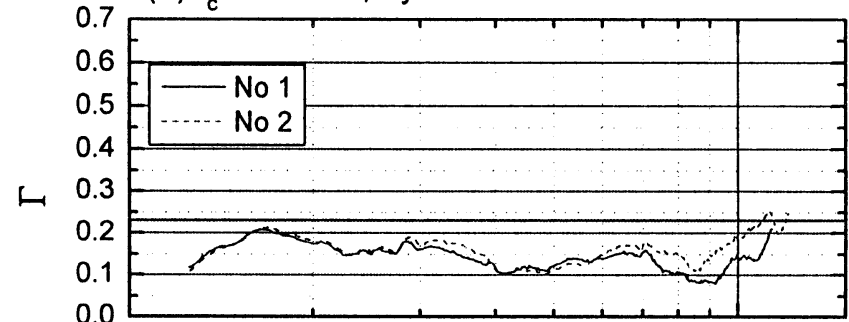

(c) $f_{c}=2.75 \mathrm{GHz}$, microstrip filter

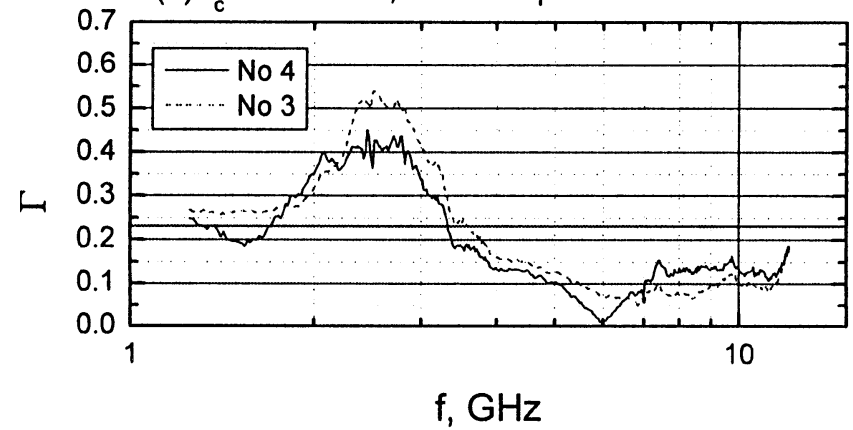

Fig. 7. Measured dependences of the reflection coefficient on frequency for the CRS with different filters: (a) lumped element filter, critical frequency of the filter $f_{\mathrm{c}}=0.75 \mathrm{GHz}$, (b) hybrid filter, $f_{\mathrm{c}}=0.5 \mathrm{GHz}$, (c) microstrip line filter, $f_{\mathrm{c}}=2.75 \mathrm{GHz}$.

reflection coefficient on frequency. It seems that the resonant behaviour that appears at higher frequency is mainly affected by the first element of the filter. Therefore, in the hybrid filter, an additional section of the transmission line made from a conductor coated with a layer of ferrite is inserted. This improves the performance of the filter in the high frequency region significantly (Fig. 7(b)) and the CRS with the hybrid filter demonstrates VSWR $<1.6$ practically over the entire tested frequency range. The reflection coefficient for the CRS with microstrip line filter is presented in Fig. 7(c). It is seen that in the frequency range of 4-12 GHz it exhibits low values of the reflection coefficient.

\subsection{Output signal}

The dependence of the output signal of the CRS on microwave pulse power over whole dynamical range of pulsed power up to $1 \mathrm{~kW}$ has been measured
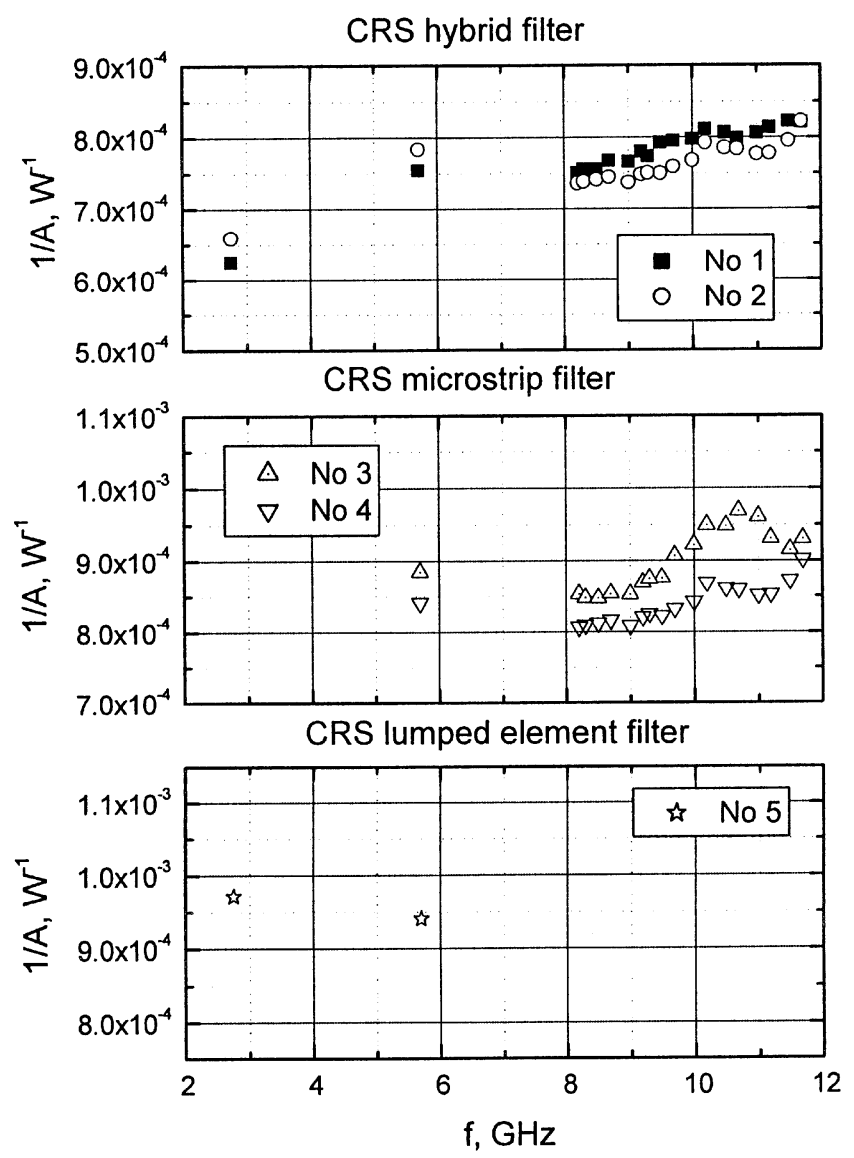

Fig. 8. The frequency dependence of the coefficient $1 / A$, defining the sensitivity of the CRS in the linear region, for the CRS with different type filters.

at three fixed frequencies in $\mathrm{S}-(f=2.75 \mathrm{GHz})$, $\mathrm{C}$ - $(f=5.7 \mathrm{GHz})$, and X-band $(f=9.3 \mathrm{GHz})$ where the powerful microwave sources providing more than $1 \mathrm{~kW}$ pulse power are in operation. The output signal for a particular device is not measured at a frequency for which VSWR $>1.6$. Therefore, the CRS with the lumped element filter is tested at S- and C-bands, the CRS with the microstrip filter is measured at $\mathrm{C}$ - and $\mathrm{X}$-bands, whereas the CRS with the hybrid filter at all frequency bands. The last two sensors have been tested in a frequency range of $8-12 \mathrm{GHz}$ as well using a TWT that outputs roughly $50 \mathrm{~W}$ pulses.

It is well known [8] that a quadratic polynomial fits well the dependence of measured microwave pulsed power on the output signal of the RS, namely

$$
P=A \frac{U_{\mathrm{S}}}{U_{0}}+B\left(\frac{U_{\mathrm{S}}}{U_{0}}\right)^{2}
$$

where the values of the parameters $A$ and $B$ are determined by fitting the measured data with Eq. (2). Using low-power pulses produced by TWT, we are able to de- 
termine the sensitivity of the CRS in the linear region only. Therefore, the frequency dependences of the parameter $1 / A$, defining the sensitivity of the CRS in a linear region, are shown in Fig. 8. It is seen that the dependence of the sensitivity on frequency for the CRS with the lumped element filter in the frequency range $2.75-5.7 \mathrm{GHz}$ is negligible $(< \pm 2 \%)$. For the CRS with the microstrip filter in the frequency range $5.7-12 \mathrm{GHz}$, the output signal variation with frequency does not exceed $\pm 7 \%$. The largest variation of the output signal was found for the CRS with the hybrid filter. It is of the order of $\pm 15 \%$ from the average value. However, it is worth mentioning that this type of CRS was tested over the widest frequency range $2.75-12 \mathrm{GHz}$. The sensitivity slightly increases with frequency for both CRSs with the hybrid filter. It should be of great importance to investigate the sensitivity of the CRS in the frequency ranges of $3-5 \mathrm{GHz}$ and $6-8 \mathrm{GHz}$.

\section{Conclusions}

It was shown that the waveguide-type RS can measure about $60 \mathrm{~dB}$ larger microwave pulse power in comparison with standard diode detectors. High reliability, long term stability, and overload resistance are characteristic of the RS. Using a DC pulse supply, the output signal up to a few tens of volts can be obtained without amplification. It was demonstrated that the waveguidetype RS can be sufficiently fast to measure as short HPM pulses as a few tens of periods of the oscillation. It was shown that the coaxial-type RS having sensitivity nearly independent of frequency $( \pm 15 \%)$ in the frequency range of $2.75-12 \mathrm{GHz}$ can be designed and manufactured. The features of the RS considered in this paper suggest that the RSs is one of the most promising devices for the measurement of the output power of pulsed HPM sources.

\section{Acknowledgement}

This work was supported in part by the European Office of Aerospace Research and Development under contract No. F61775-02-WE030.

\section{References}

[1] High-Power Microwave Sources and Technologies, eds. R.J. Barker and E. Schamiloglu, Series on RF and Microwave Technologies (IEEE Press, Pistcataway, NJ, 2001).

[2] V. Dienys and J. Požela, Hot Electrons (Mintis, Vilnius, 1971) [in Russian].

[3] M. Dagys, Ž. Kancleris, V. Orševski, and R. Simniškis, High-power microwave pulse measurement using resistive sensors, IEEE Trans. Instrum. Meas. 46(2), 499502 (1997).

[4] J.A. Lozovik, A.V. Mylnikov, and I.L. Khomenko, Reference measurement of microwave pulse power, Electronics Technique: Ser. Microwave Technique 1, 50-53 (1977) [in Russian].

[5] M. Dagys, Ž. Kancleris, V. Orševskis, and R. Simniškis, Resistive sensor for high power short pulse microwave measurement in waveguides, Electron. Lett. 31(16) 1355-1357 (1995).

[6] L.D. Moreland, E. Schamiloglu, R.W. Lemke, S.D. Korovin, V.V. Rostov, A.M. Roitman, K.J. Hendricks, and T.A. Spencer, Efficiency enhancement of high power vacuum BWO's using nonuniform slow wave structures, IEEE Trans. Plasma Sci. 22(3) 554-565 (1994).

[7] M. Dagys, Ž. Kancleris, R. Simniškis, E. Schamiloglu, and F.J. Agee, Application of resistive sensors for short high-power microwave pulse measurement, in: 12th IEEE Int. Pulsed Power Conference Proceedings (Monteray, CA, USA, June 27-30, 1999) pp. 829-832.

[8] M. Dagys and J. Skucas, Dynamic range and possibilities of it expansion for resistive sensors of microwave electric field, Izv. Vyssh. Uchebn. Zaved. Radioelektronika 23, 65-69 (1980) [in Russian]. 


\title{
REZISTORINIS JUTIKLIS DIDELĖS GALIOS MIKROBANGŲ IMPULSAMS MATUOTI
}

\author{
Ž. Kancleris, M. Dagys, R. Simniškis \\ Puslaidininkiu fizikos institutas, Vilnius, Lietuva
}

\begin{abstract}
Santrauka
Pateikti puslaidininkiniai rezistoriniai jutikliai (RJ), skirti didelès galios mikrobangu impulsams matuoti. Jutiklių veikimas pagrịstas krūvininkų kaitimo efektu stipriame elektriniame lauke. Patalpinus puslaidininkini bandini perdavimo linijoje ir išmatavus varžos pokytị, atsirandantị dèl krūvininkų kaitimo mikrobangos impulso elektriniame lauke, ivvertinama sklindančio linija mikrobangos impulso galia. Pateikti eksperimentiniai strypinių bangolaidinių RJ rodmenu palyginimo su Rusijos mikrobangų impulsų etalonu rezultatai per 18 metų, parodantys puiku RJ ilgalaiki stabilumą. Sukurti greitaveikiai diafragminiai RJ, galintys išmatuoti nanosekundinès trukmès didelès galios mikrobangų impulsus. Panaudojus RJ maitinimui $50 \mathrm{~V}$ amplitudès pastovios srovès impulsus,
\end{abstract}

gautas kelių dešimčių voltų išèjimo signalas nenaudojant stiprintuvo. Didelis išèjimo signalas yra svarbus matuojant didelès galios mikrobangu impulsus, nes irrenginių, generuojančiu tokius impulsus, aplinkoje būdingi stiprūs trikdžiai. Greitaveikių diafragminių RJ sparta patikrinta, matuojant $7 \mathrm{~ns}$ trukmès $500 \mathrm{MW}$ impulsus, generuojamus SINUS įrenginio New Mexico universitete. Sukurti koaksialiniai RJ, tinkami matuoti $1 \mathrm{~kW}$ galios mikrobangų impulsus plačiame dažnių ruože $(2-12 \mathrm{GHz})$. Ištirta keletas koaksialinių RJ atmainų, turinčių skirtingus žemo dažnio filtrus. Paaiškejjo, kad koaksialinių RJ, turinčių kombinuotą žemo dažnio filtrą, jautrio būdingosios dažninès kreivès netolygumas neviršija $\pm 15 \%$. RJ savybės akivaizdžiai parodo, kad tokie jutikliai yra vieni iš perspektyviausių prietaisų didelès galios mikrobangų impulsams registruoti. 